\begin{tabular}{|l|l|r|}
\hline A1 Fitrah & Kesulitan Anak Usia Dini dalam \\
Jerinteraksi Sosial di TK N 09 \\
Bengkulu Selatan \\
ISSN : 2599-2287 E-ISSN : 2622-335X & Puspita RO, Nurlaili, \\
Vol.3 No.1Juli 2019 & Ahmad Syarifin \\
\hline
\end{tabular}

\title{
KESULITAN ANAK USIA DINI DALAM BERINTERAKSI SOSIAL DI TK NEGERI 09 BENGKULU SELATAN
}

\begin{abstract}
Abstrak
Penelitian ini dilatar belakangi oleh adanya kesulitan anak dalam berinteraksi sosial. Hal ini dapat dilihat dari siswa yang memiliki perilaku masih suka menyendiri, tidak bisa mengendalikan tindakakan dan perasaannya, tidak mau berbagi, serta belum mau bekerja sama. Dari berbagai perilaku anak tersebut diketahui ada anak yang masih suka menyendiri, tidak bisa mengendalikan tindakan dan perasaannya dengan wajar saat bermain, ada yang tidak mau berbagi, serta tidak mau bekerjasama. Hal itu sebenarnya tidak perlu terjadi apabila interaksi teman sebaya dapat diterapkan dengan baik agar perilaku sosial anak selalu terpelihara Rumusan masalah dalam penelitian ini yaitu bagaimana kesulitan anak usia dini dalam berinteraksi sosial di TK Negeri 09 Bengkulu Selatan. Tujuan dari penelitian ini adalah mengetahui bagaimana kesulitan anak usia dini dalam berinteraksi sosial di TK Negeri 09 Bengkulu Selatan. Metode penelitian yang digunakan adalah penelitian kualitatif. Hasil penelitian disimpulkan bahwa kegiatan bermain pada anak di TK Negeri 09 Bengkulu Selatan menekankan pada peranannya dalam kemampuan interaksi sosial anak, karena kemampuan ini berperan penting bagi pekembangan anak. Dalam mengikuti pembelajaran ada kesulitan anak dalam berinteraksi sosial diantaranya yaitu kurang peduli dan lebih suka sendirian, sesekali mau berinteraksi dengan teman-temannya namun hanya sebatas teman yang berada disebelahnya, kurang percaya diri dalam berinteraksi dengan teman-temannya dan cenderung kurang berani untuk berbicara langsung. Sedangkan untuk minat tertahan karena mereka kurang berani untuk berinteraksi dan cenderung takut. Faktor yang mempengaruhi kesulitan anak dalam berinteraksi sosial ini yaitu adalah perbedaan umur, kurangnya rasa percaya diri dan keberanian anak serta minat meskipun tidak berperan besar.
\end{abstract}

Kata Kunci: Kesulitan, Anak Usia Dini, Berinteraksi Sosial 


\begin{tabular}{|l|l|r|}
\hline Al Fitrah & Kesulitan Anak Usia Dini dalam \\
Journal Of Early Childhood Islamic Education & Berinteraksi Sosial di TK N 09 \\
Bengkulu Selatan \\
ISSN : 2599-2287 E-ISSN : 2622-335X & Puspita RO, Nurlaili, \\
Vol.3 No.1Juli 2019 & Ahmad Syarifin \\
\hline
\end{tabular}

\section{PENDAHULUAN}

Pendidikan merupakan kebutuhan mutlak yang harus dipenuhui sepanjang hayat manusia. Tanpa pendidikan mustahil bagi manusia untuk dapat berkembang sejalan dengan aspiriasinya untuk maju, sejahtera dan bahagia menurut konsep pandangan hidup mereka, pendidikan merupakan salah satu wadah penambahan pengalaman bagi peserta didik. Pendidikan mempunyai tugas dan tanggung jawab yang cukup berat dalam membentuk arah anak, yang diterima oleh anak akan membentuk masa depan itu sendiri.

Pendidikan nasional merupakan acuan dari semua jenis dan jenjang pendidikan di Indonesia sebagai harapan bangsa. Dengan demikian pendidikan merupakan jalan utama bagi manusia untuk dapat mencapai kesejateran. Salah satu dari pendidikan yang di wajibkan bagi manusia Indonesia yaitu jenjang pendidikan formal yaitu dibagi menjadi beberapa tingkatan, dimulai dari taman kanak-kanak, sekolah dasar, sekolah menengah pertama, sekolah menengah atas sampai dengan kepeguruan tinggi. ${ }^{1}$

Pendidikan dan pengajaran diarahkan untuk membentuk manusia yang diidamkan, berkualitas, beriman dan bertaqwa kepada Tuhan Yang Maha Esa, berbudi pekerti luhur, berkepribadian, disiplin, berkerja keras, bertanggung jawab, mandiri, cerdas dan trampil serta sehat jasmani dan rohani. Sosok manusia yang diharapakan adalah manusia yang mampu dan bertanggun jawab. Untuk menciptakan manusia yang diidamkan membutuhkan seorang guru yang mempunyai keahlian di bidangnya. Karena guru merupakan salah satu unsur penyeimbang di bidang pendidikan dan harus berperan serta secara aktif dan menempatkan kedudukannya

\footnotetext{
${ }^{1}$ Undang-undang RI Nomor 20, Tentang Sistem Pendidikan Nasional, (Bandung: Citra Umban, 2003). h. 26-27.
}

sebagai tenaga pengajar yang professional, harus sesuai dengan tuntutan dan kebutuhan masyarakat, artinya setiap rencana guru harus dapat diprioritaskan menjaga kebaikan yang dibenarkan semata-mata demi kepentingan peserta didik.

Guru dan Dosen mengamanatkan bahwa guru adalah pendidik profesional dengan tugas utama mendidik, mengajar, membimbing, mengarahkan, melatih, menilai, dan mengevaluasi peserta didik pada pendidikan anak usia dini jalur pendidikan formal, pendidikan dasar dan pendidikan menengah. ${ }^{2}$

Kompetensi guru merupakan seperangkat pengetahuan, keterampilan dan prilaku yang harus dimiliki, dihayati, dikuasai dan diwujudkan oleh guru dalam melaksanakan tugas keprofesionalannya. Kompetensi guru dapat dimaknai sebagai kebulatan pengetahuan, keterampilan dan sikap yang berwujud tindakan cerdas dan penuh tanggung jawab dalam melaksanakan tugas sebagai agen pembelajaran. Kompetensi guru meliputi kompetensi kepribadian, pedagogik, profesional dan sosial. Keempat kompetensi tersebut dapat diperoleh melalui pendidikan akademik sarjana atau diploma empat, pendidikan profesi ataupun melalui pembinaan dan pengembangan profesi guru. ${ }^{3}$

Guru yang berkompeten memiliki pemahaman terhadap karakteristik peserta didik, penguasaan bidang studi baik dari sisi keilmuan maupun kependidikan, kemampuan penyelenggaraan pembelajaran yang mendidik, kemauan dan kemampuan mengembangkan profesionalitas dan kepribadian secara berkelanjutan. ${ }^{4}$

\footnotetext{
${ }^{2}$ Undang-Undang RI Nomor 14 tahun 2005, Tentang Guru dan Dosen...h.7.

${ }^{3}$ Sarimaya Farida, Sertifikasi Guru,

(Bandung: Yrama Widya, 2009), h. 17.

${ }^{4}$ Sarimaya Farida, Sertifikasi Guru...,h. 17.
} 


\begin{tabular}{|l|l|r|}
\hline & Al Fitrah & Kesulitan Anak Usia Dini dalam \\
Journal Of Early Childhood Islamic Education & Berinteraksi Sosial di TK N 09 \\
ISSN : 2599-2287 E-ISSN : 2622-335X & Beluatan \\
Vol.3 No.1Juli 2019 & Puspita RO, Nurlaili, \\
Ahmad Syarifin \\
\hline
\end{tabular}

Setiap siswa pada prinsipnya tentu berhak memperoleh peluang yang sama untuk mencapai kinerja akademik yang memuaskan. Namun dalam kenyataan sehari-hari nampak jelas antara kemampuan siswa yang satu dengan yang lain berbeda. Sementara dalam praktiknya pendidikan di sekolah ditujukan bagi siswa yang berkemampuan rata-rata sehingga siswa yang berkemampuan lebih atau kurang terabaikan, dari sini timbullah apa yang disebut kesulitan belajar yang bisa menimpa semua kalangan. ${ }^{5}$

Aktivitas belajar bagi setiap individu tidak selamanya berlangsung secara wajar kadang-kadang lancar, kadang-kadang tidak, kadang-kadang dapat cepat menangkap apa yang dipelajari kadangkadang terasa amat sulit. Salah satu faktor penyebab kesulitan belajar adalah karena tidak adanya minat seseorang terhadap suatu mata pelajaran yang akan menimbulkan kesulitan belajar. Belajar yang tidak ada minatnya mungkin tidak sesuai dengan bakatnya, kebutuhannya, kecakapannya atau tidak sesuai dengan tipe-tipe khusus anak banyak menimbulkan problema pada dirinya. Karena itu pelajaran pun tidak pernah terjadi pada otak, akibatnya timbul kesulitan belajar.

Penelitian ini dilatar belakanging masih terdapat di antara siswa yang memiliki perilaku sosial tidak sesuai dengan yang diharapkan diantaranya, ada anak yang masih suka menyendiri, tidak bisa mengendalikan tindakan dan perasaannya, tidak mau berbagi, serta tidak mau bekerjasama.Tujuan penelitian ini dilakukan untuk mengetahui hubungan antara interaksi sosial teman sebaya dengan perilaku sosial anak. ${ }^{6}$

Masa usia dini adalah masa yang sangat penting dalam sepanjang perjalan hidup manusia, karena pada masa ini

${ }^{5}$ Muhibbin Syah, Psikologi Belajar (Jakarta: Rajawali Pers, 209), h. 172.

${ }^{6}$ Hasil Observasi awal pada 2 Desember 2015. merupakan masa pembentukan pondasi dan dasar kepribadian yang akan menentukan pengalaman anak selanjutnya, seperti halnya yang dikemukakan oleh Hurlock bahwa tahun-tahun awal kehidupan anak merupakan dasar yang cenderung bertahan dan mempengaruhi sikap dan prilaku anak sepanjang hidupnya. Masa ini anak memiliki karakteristik yang khas, baik secara fisik, psikis, moral dan sebagainya. ${ }^{7}$

Bagi orang dewasa, bermain hanyalah kegiatan untuk mengisi waktu luang. Tetapi bagi anak-anak, bermain merupakan pekerjaan yang sangat penting. Melalui kegemaran bermain, akal dan fisik mereka menjadi berkembang. Aktivitas bermain juga akan menyempurnakan fungsi-fungsi sosial, emosional, dan inteligensinya, yang mencangkup kegiatan berpikir, problem solving (pemecahan masalah) dan kecepatan imaginasi. Bagaimana pun juga lingkungan fisik dan bimbingan orang tua memainkan peran-peran yang nyata dalam menentukkan kemampuan-kemampuan anak dan perkembangan kecerdasannya .

Namun pada kenyataannya ada orang tua yang kurang memperhatikan perkembangan anak mereka melalui kegiatan bermainnya. Terbukti akhir-akhir ini berkembang kecenderungan di masyarakat untuk memperkenalkan berbagai cara kegiatan belajar sejak masa kanak-kanak sedini mungkin. Berbagai alasan dikemukakan tentang betapa perlunya berbagai potensi anak yang dipacu perkembangannya, terutama menyangkut intelegensi. Berbagai buku telah beredar untuk membuktikan betapa proses pembelajaran pada anak dapat di percepat, tanpa menunggu tibanya masa sekolah

Dari fenomena tersebut, bisa dilihat kesalahan yang terjadi adalah karena orang tua maupun guru belum paham betul akan pribadi anak secara utuh, baik sifat-sifatnya, kecenderungannya, maupun kodrat sifata

${ }^{7}$ Elisabeth B Hurlock. Child Development (Terjemahan) (Jakarta: Gelora Aksara Pratama, 1991), h. 27. 


\begin{tabular}{|l|l|r|}
\hline A1 Fitrah & Kesulitan Anak Usia Dini dalam \\
Journal Of Early Childhood Islamic Education & Berinteraksi Sosial di TK N 09 \\
Bengkulu Selatan \\
ISSN : 2599-2287 E-ISSN : 2622-335X & Puspita RO, Nurlaili, \\
Vol.3 No.1Juli 2019 & Ahmad Syarifin \\
\hline
\end{tabular}

anak-anaknya, serta belum paham akan nilai-nilai yang terkandung dalam bermain, seperti nilai-nilai fisik, pendidikan, sosial, moral, inovatif, individual dan pengobatan.

Oleh karena itu bisa dipahami, bahwa pada periode kanak-kanak dunianya adalah bermain dan merupakan masa yang strategis untuk menerima ilmu pengetahuan dan mengembangkan diri. Bagi anak, bermain bersama dengan teman sebaya adalah merupakan salah satu syarat kemajuan bagi anak dan banyak mengandung nilai-nilai pendidikan, misalnya dapat melatih bergaul dan menyesuaikan diri dengan teman-temaaan sebaya, belajar mengindahkan hak orang lain dan belajar untuk menghasilkan sesuatu dalam kerjasama, serta sebagai sarana untuk menyalurkan minat dan bakat anak. Maka sangatlah efektif jika menanamkan jiwa sosial anak melalui permainan atau bermain.

Pendidikan Taman Kanak-kanak (TK) sebagai bagian dari pendidikan prasekolah telah diatur oleh Undang-undang Nomor 20 Tahun 2003 tentang pendidikan nasional menyebutkan bahwa pendidikan anak usia dini adalah suatu upaya pembinaan yang ditunjukkan kepada anak sejak lahir sampai dengan usia 6 tahun yang dilakukan melalui pemberian rangsangan pendidikan untuk membantu pertumbuhan dan perkembangan jasmani dan rohani agar anak memiliki kesiapan dalam memasuki pendidikan lebih lanjut.

Taman Kanak-kanak merupakan salah satu bentuk pendidikan prasekolah yang ada di jalur pendidikan formal. Pendidikan prasekolah adalah pendidikan untuk membantu pertumbuhan, perkembangan, jasmani dan rohani anak di luar lingkungan keluarga sebelum memasuki pendidikan dasar. ${ }^{8}$ Masa usia TK merupakan masa-

${ }^{8}$ Yeni Rachmawati \& Euis Kurniati. Strategi Pengembangan Kreativitas Pada Anak UsiaTaman Kanak Kanak. (Jakarta: Departemen Pendidikan Nasional,Direktorat Jendral Pendidikan Tinggi,Direktorat Pembinaan Pendidikan Tenaga masa dalam kehidupan manusia yang berada pada rentangusia empat tahun sampai usia enam tahun. ${ }^{9}$

Taman kanak-kanak didirikan sebagai usaha mengembangkan seluruh segi kepribadian anak didik dalam rangka menjembatani pendidikan dalam keluarga kependidikan sekolah. TK merupakan salah satu bentuk pendidikan prasekolah adalah pendidikan untuk membantu pertumbuhan dan perkembangan jasmani dan rohani anak didik di luar lingkungan keluarga sebelum memasuki pendidikan dasar.

Di taman kanak-kanak anak mulai diberi pendidikan secara berencana bagi anak. Namun demikian Taman Kanakkanak harus tetap merupakan tempat yang menyenangkan bagi anak. Tempat tersebut baiknya dapat memberikan perasaan aman, nyaman dan menarik bagi anak serta mendorong keberanian dan merangsang untuk berekplorasi atau menyelidiki dan mencari pengalaman demi perkembangan kepribadiannya secara optimal, dengan bermain anak dapat melakukan kegiatan yang merangsang dan mendorong memperlancar perkembangan kemampuan anak.

Berdasarkan hasil observasi yang dilakukan di TK Negeri 09 Bengkulu Selatan, peneliti menemukan masih terdapat di antara siswa yang memiliki perilaku masih suka menyendiri, tidak bisa mengendalikan tindakan dan perasaannya, tidak mau berbagi, serta belum mau bekerja sama. Dari berbagai perilaku anak tersebut diketahui ada anak yang masih suka menyendiri, tidak bisa mengendalikan tindakan dan perasaannya dengan wajar saat bermain, ada yang tidak mau berbagi, serta tidak mau bekerjasama. Hal itu sebenarnya tidak perlu terjadi apabila

Kependidikan dan Ketenagaan Perguruan Tinggi, 2005), h. 1

${ }^{9}$ M. Ramli. Pendampingan Perkembangan Anak Usia Dini. Jakarta: Depdiknas, Dirjen Pendidikan Tinggi, Direktorat Pembinaan Pendidikan Tenaga Kependidikan dan Ketenagaan Perguruan Tinggi, 2005), h. 185. 


\begin{tabular}{|l|l|r|}
\hline & Al Fitrah & Kesulitan Anak Usia Dini dalam \\
Journal Of Early Childhood Islamic Education & Berinteraksi Sosial di TK N 09 \\
ISSN : 2599-2287 E-ISSN : 2622-335X & Belatan \\
ISS & Puspita RO, Nurlaili, \\
Vol.3 No.1Juli 2019 & Ahmad Syarifin \\
\hline
\end{tabular}

interaksi teman sebaya dapat diterapkan dengan baik agar perilaku sosial anak selalu terpelihara. Jumlah keseluruhan anak dari kelas A dan B yaitu berjumlah 35 siswa.

Berdasarkan latar belakang masalah ini penulis bermaksud menggali, mengetahui atau akan mencoba dan berusaha semaksimal mungkin menggali, mengetahui atau mengungkapkan permasalahan-permasalahan dimaksud yang dituangkan kedalam skripsi "Kesulitan Anak Usia Dini dalam Berinteraksi Sosial di TK Negeri 09 Bengkulu Selatan”.

\section{Landasan Teori}

\section{Pengertian Interaksi Sosial}

Interaksi sosial adalah hubungan antara dua atau lebih individu dimana kelakuan individu yang satu mempengaruhi, mengubah, atau memperbaiki kelakuan individu yang lain atau sebaliknya. Hubungan antara anak dengan teman sebaya merupakan bagian dari interaksi sosial yang dilakukan anak di lingkungan sekolah maupun lingkungan masyarakat. Dalam berinteraksi dengan teman sebaya, anak akan memilih anak lain yang usianya hampir sama dan di dalam berinteraksi dengan teman sebaya lainnya, anak dituntut untuk dapat menerima teman sebayanya. Dalam penerimaan teman sebayanya anak harus mampu menerima persamaan usia, menunjukkan minat terhadap permaian, dapat menerima teman lain dari kelompok, atau dapat lepas dari orang tua atau orang dewasa lain, dan menerima kelas sosial yang berbeda. ${ }^{10}$

Interaksi sosial ini yang disebut dengan proses sosial yaitu cara-cara berhubungan yang dilihat apabila perorangan dan kelompok-kelompok

\footnotetext{
${ }^{10}$ Nana Syaodih Sukmadinata, Landasan

Psikologis Pendidikan. Bandung: Remaja

Rosdakarya, 2008), h. 43
}

sosial saling bertemu dan menentukan sistem serta bentuk-bentuk hubungan ini, atau apa yang akan terjadi apabila ada perubahan-perubahan yang menyebabkan goyahnya pola-pola kehidupan yang telah ada. ${ }^{11}$

Pengertian interaksi sosial dalam Kamus Besar Bahasa Indonesia adalah hubungan sosial yang dinamis antara orang perseorangan, antara perseorangan dan kelompok, dan antara kelompok dan kelompok. Maksudnya bahwa interaksi ini tidak hanya terjadi antara anak dengan anak saja, melainkan terjadi hubungan yang dinamis antara anak dengan kelompok maupun hubungan antar kelompok. ${ }^{12}$

\section{Konsep Pendidikan Anak usia Dini}

Pendidikan Anak Usia Dini (PAUD) adalah jenjang pendidikan sebelum jenjang pendidikan dasar yang merupkan suatu upaya pembinaan yang ditujukan bagi anak sejak lahir sampai dengan usia enam tahun yang dilakukan melalui pemberian rangsangan pendidikan untuk membantu pertumbuhan dan perkembangan jasmani dan rohani agar anak memiliki kesiapan dalam memasuki pendidikan lebih lanjut.

Guna memperjelas pemahaman tentang konsep pendidikan anak usia dini maka terlebih dahulu akan dipaparkan beberapa pengertian tentang pendidikan anak usai dini :

a) Menurut Marjory Ebbeck seorang pakar anak usia dini dari Australia menyatakan bahwa pendidikan anak usia dini adalah pelayanan kepada anak mulai lahir sampai umur 8 tahun

b) Menurut Undang-Undang RI Nomor. 21 Tahun 2003 tentang

\footnotetext{
${ }^{11}$ Kartini Kartono, Psikologi Perkembangan. (Jakarta: Rineka Cipta. 2010), h. 66

${ }^{12}$ Chulsum dan Novia. Kamus Besar Bahasa Indonesia. (Surabaya: Kashiko, 2006), h. 335.
} 
Sistem Pendidikan Nasional menyatakan bahwa pendidikan anak usia dini adalah suatu upaya pembinaan yang ditujukan kepada anak sejak lahir sampai umur 6 tahun yang dilakukan melalui pemberian rangsangan pendidikan untuk membantu pertumbuhan dan perkembangan jasmani dan rohani anak agar memiliki kesiapan dalam memasuki pendidikan lebih lanjut.

c) Menurut penulis, maka pendidikan anak usia dini adalah upaya yang terencana dan sistematis yang dilakukan oleh pendidik atau pengasuh anak usia dini $0-8$ tahun dengan tujuan agar anak mampu mengembangkan potensi yang dimiliki secara optimal.

\section{Pengertian Guru}

Guru adalah semua orang yang berwenang dan bertanggung jawab untuk membimbing dan membina anak didik, baik secara individual maupun klasikal, di sekolah maupun di luar sekolah. Guru adalah orang yang kerjanya mengajar atau memberikan pelajaran di sekolah atau kelas. Secara lebih khusus lagi ia mengatakan bahwa guru adalah "orang yang bekerja dalam bidang pendidikan dan pengajaran yang ikut bertanggung jawab dalam membantu anak-anak mencapai kedewasaan masing-masing. ${ }^{13}$

Guru merupakan orang yang harus digugu dan ditiru, dalam artian orang yang memiliki kharisma dan wibawa sehingga perlu untuk ditiru dan diteladani. Istilah guru memiliki beberapa istilah, seperti ustad, muallim, muaddib, dan murabbi. Istilah muallim lebih menekankan guru sebagai pengajar dan penyampai pengetahuan (knowledge) dan ilmu (science); istilah muaddib lebih menekankan guru

${ }^{13}$ Syaiful Bahri Djamarah, Guru dan Anak Didik Dalam Interaksi Edukatif, (Jakarta: PT Asdi Mahasatya, 2005), h. 32. sebagai pembina moralitas dan akhlak peserta didik dengan keteladanan; sedangkan istilah murabbi lebih menekankan pengembangan dan pemeliharaan baik aspek jasmaniah maupun ruhaniah. Sedangkan istilah yang umum dipakai dan memiliki cakupan makna yang luas dan netral adalah ustad yang dalam Bahasa Indonesia diterjemahkan sebagai "guru

Guru/pendidik adalah orang yang bertanggung jawab dalam menginternalisasikan nilai-nilai religius dan berupaya menciptakan individu yang memiliki pola pikir yang ilmiah dan pribadi yang sempurna. ${ }^{14}$

Berdasarkan beberapa pengertian di atas guru adalah seseorang yang didengar ucapanya dan ditiru perbuatannya dan mempunyai tanggung jawab yang besar dalam membimbing dan membina anak didik baik secara individual atau klasikal, di sekolah maupun di luar sekolah, agar memiliki pola pikir yang ilmiah dan pribadi yang sempurna.

\section{Metode Penelitian}

Jenis penelitian ini adalah penelitian kualitatif. Penelitian kualitatif adalah prosedur penelitian yang menghasilkan data deskriptif berupa kata-kata tertulis, atau lisan dari orang-orang dan perilaku yang dapat diamati. Penelitian ini adalah penelitian lapangan (field research) sedangkan metode yang digunakan adalah deskriptif. ${ }^{15}$ Berdasarkan definisi penelitian deskriptif ini maka penelitian ini dimaksudkan untuk menggambarkan kesulitan anak usia dini dalam berinteraksi sosial di TK Negeri 09 Bengkulu Selatan.

\footnotetext{
${ }^{14}$ Ramayulis. Ilmu Pendidikan Islam. (Jakarta: Kalam Mulia, 2008), h. 85.

${ }^{15}$ Lexy J Moelong, Meodologi Penelitian Kualitatif, (Jakarta: Rosda, 2010), h. 45.
} 


\begin{tabular}{|l|l|r|}
\hline A1 Fitrah & Kesulitan Anak Usia Dini dalam \\
Journal Of Early Childhood Islamic Education & Berinteraksi Sosial di TK N 09 \\
Bengkulu Selatan \\
ISSN : 2599-2287 E-ISSN : 2622-335X & Puspita RO, Nurlaili, \\
Vol.3 No.1Juli 2019 & Ahmad Syarifin \\
\hline
\end{tabular}

\section{Pembahasan}

Taman Kanak-Kanak Negeri 09 Bengkulu selatan adalah salah satu jenjang pendidikan sebelum jenjang pendidikan dasar yang merupkan suatu upaya pembinaan yang ditujukan bagi anak sejak lahir sampai dengan usia enam tahu. Pendidikan anak usia dini adalah proses pemberian rangsangan pendidikan untuk membantu pertumbuhan dan perkembangan jasmani dan rohani agar anak memiliki kesiapan dalam memasuki pendidikan lebih lanjut.

Dalam proses pembelajaran ada beberapa anak yang mengalami kesulitan dalam belajar salah satunya adalah kesulitan berinteraksi sosial dengan lingkungannya. Sebagaimana dijel;askan bahwa interaksi sosial adalah hubungan antara dua atau lebih individu dimana kelakuan individu yang satu mempengaruhi, mengubah, atau memperbaiki kelakuan individu yang lain atau sebaliknya. Hubungan antara anak dengan teman sebaya merupakan bagian dari interaksi sosial yang dilakukan anak di lingkungan sekolah maupun lingkungan masyarakat. Dalam berinteraksi dengan teman sebaya, anak akan memilih anak lain yang usianya hampir sama dan di dalam berinteraksi dengan teman sebaya lainnya, anak dituntut untuk dapat menerima teman sebayanya. Dalam penerimaan teman sebayanya anak harus mampu menerima persamaan usia, menunjukkan minat terhadap permaian, dapat menerima teman lain dari kelompok, atau dapat lepas dari orang tua atau orang dewasa lain, dan menerima kelas sosial yang berbeda.

Kemampuan untuk melakukan interaksi sosial merupakan hal yang harus dimiliki oleh setiap individu, begitu juga dengan anak usia dini. Setiap anak berbeda satu sama lainnya, mereka memiliki keunikan tersendiri. Dalam melakukan proses interaksi tersebut, setiap anak tentunya mendapatkan pengaruh dari berbagai hal di sekitarnya maupun yang berasal dari dalam dirinya sendiri. Apabila anak mengalami masalah dalam berinteraksi sosial, maka diperlukan bimbingan dan arahan dari berbagai pihak.

Kemampuan berinteraksi pada anak terdiri dari beberapa hal yaitu: berbicara dengan baik dan sopan, menyampaiakan pesan dengan runtut, menceritakan kejadian yang dialami, bercerita di depan kelas, mendengarkan orang yang sedang berbicara, memanggil dan menyapa teman sebaya, dan mengambil pola pergiliran bicara. Komunikasi dua arah merupakan sarana anak belajar untuk berinteraksi dengan orang dewasa maupun dengan teman sebaya selain itu juga dapat meningkatkan kemampuan berteman dan berinteraksi dengan teman sebaya secara positif. Indikator keterampilan berkomunikasi pada anak sebagai inti dari kemampuan interakasi sosial adalah anak menyapa teman apabila bertemu, anak dapat berkomunikasi dengan temannya dalam kegiatan pembelajaran, anak mengucapkan tolong apabila meminta bantuan, anak mendengarkan penjelasan pendidik, anak bertanya pada pendidik dalam kegaitan pembelajaran, anak mendengarkan orang yang sedang berbicara, anak dapat menceritakan apa yang anak rasakan.

Berdsarkan hasil penelitian diketahui kemampuan interaksi sosial dilihat dari kontak sosial yaitu sebagai berikut, anak menyapa sesama temanya, anak saling berjabat tangan ketika awal masuk kelas, mau tersenyum ketika bertemu dengan temannya. Dilihat dari komunikasi anak sering mengajak bicara temannya, suka bercanda, bahasa jelas lancar dan dapat dimengerti, berani bertanya pada temannya atau gurunya, berani mengutarakan berpendapat. Dan dari kerjasama anak membantu temannya menempel, mengguting, saling berbagi makanan atau minuman, saling meminjamkan temannya alat-alat tulis untuk tugas bersama kelompok, menolong 


\begin{tabular}{|l|l|r|}
\hline Al Fitrah & Kesulitan Anak Usia Dini dalam \\
Journal Of Early Childhood Islamic Education & Berinteraksi Sosial di TK N 09 \\
Bengkulu Selatan \\
ISSN : 2599-2287 E-ISSN : 2622-335X & Puspita RO, Nurlaili, \\
Vol.3 No.1Juli 2019 & Ahmad Syarifin \\
\hline
\end{tabular}

temannya yang jatuh, cepat tanggap, peduli sesama teman yang tidak masuk sekolah membantu teman dengan memberi tahu kepada guru bahwa ada temannya yang tidak masuk, bermain bersama dengan banyak teman. Sedangkan contoh kemampuan interaksi sosial yang kurang yaitu anak lebih banyak diam, cuek, tidak tanggap, malu, minder, tidak bisa bergaul dengan teman yang lain, temannya terbatas, sibuk dengan mainannya sendiri, suka menyendiri, jarang menyapa teman, kalau berbicara bertanya atau berpendapat terkadang dibantu oleh mamanya.

Selanjutnya ada 4 kelompok pengembangan keterampilan sosial yang dipelajari anak di taman kanak-kanak yakni keterampilan dalam kaitan membina hubungan dengan orang dewasa, membina hubungan dengan kelompok dan membina diri sebagai individu. Proses sosialisasi adalah mengenal tingkah laku yang dapat diterima oleh masyarakat dan diharapkan dilakukan anak, serta belajar mengendalikan diri. Hasil yang diperoleh dari proses sosialisasi tersebut merupakan keterampilan sosial yang mempunyai kedudukan yang strategis bagi anak untuk dapat membina hubungan antar pribadi dalam berbagai lingkungan dan kelompok orang.

Untuk melakukan hal tersebut, perlu diketahui faktor-faktor yang berperan dalam mempengaruhi interaksi sosial anak. Dalam penelitian ini, faktor-faktor yang berasal dari dalam diri anak atau yang bersifat internal yaitu konsep diri anak dan minat sosial pada teman sebaya. Sedangkan faktor-faktor yang berasal dari luar diri anak atau yang bersifat eksternal yaitu pengaruh teman sebaya, dorongan dari guru, dan tingkat pendidikan orang tua. Terkait dengan konsep diri anak, berdasarkan hasil wawancara yang peneliti lakukan terhadap guru selaku informan, baik itu guru yang merupakan wali kelas maupun guru yang berperan sebagai guru pendamping di kelas, sebagian besar guru mengatakan bahwa faktor kepercayaan diri ataupun keyakinan dalam diri anak memegang peranan penting dalam mempengaruhi kemampuan berinteraksi sosialnya. Selain itu, pada hasil observasi yang telah dilakukan, tampak bahwa faktor kepercayaan diri anak mempengaruhi interaksi sosialnya. Hal ini tampak ketika anak masih terlihat menyendiri dan menarik diri dalam kegiatan bersama. Anak terlihat kurang berani dan cenderung kurang percaya diri dalam menampilkan dirinya ketika bersama teman-temannya. Dalam hal ini dengan adanya kepercayaan diri pada anak maka akan mempengaruhi hubungan sosialnya dengan orang lain, terutama dengan teman-teman sebayanya.

Ada 8 faktor yang mempengaruhi kemampuan interaksi sosial anak. Faktor pertama adalah adanya kesempatan untuk bergaul dengan orang-orang di sekitarnya dari berbagai usia dan latar belakang. Semakin banyak kesempatan yang diberikan kepada anak untuk bergaul dengan orang-orang yang ada di lingkuannya dengan latar belakang dan usia yang berbeda-beda akan dapat mengembangkan kemampuan sosialnya. Faktor kedua adalah banyak dan bervariasinya pengalaman dalam bergaul dengan orang-orang di lingkungan. Semakin banyak dan bervariasi pengalaman dalam bergaul dengan orang-orang di lingkungannya, maka akan semakin banyak pula hal-hal yang dipelajarinya untuk menjadi bekal dalam meningkatkan ketrampilan sosialnya. Faktor ketiga adalah adanya minat dan motivasi untuk bergaul. Lingkungan yang mendukung dan menyenangkan akan membuat minat dan motivasinya bergaul semakin berkembang. Faktor keempat yang mempengaruhi interaksi sosial anak adalah banyaknya pengalaman yang menyenangkan yang diperoleh melalui pergaulan dan aktivitas sosial. Semakin banyak pengalaman yang menyenangkan yang diperoleh melalui pergaulan dan aktivitas sosialnya, maka 


\begin{tabular}{|l||l|r|}
\hline Al Fitrah & Kesulitan Anak Usia Dini dalam \\
Jerinteraksi Sosial di TK N 09 \\
Bengkulu Selatan \\
ISSN : 2599-2287 E-ISSN : 2622-335X & Puspita RO, Nurlaili, \\
ISThal & Ahmad Syarifin \\
\hline
\end{tabular}

keinginan untuk bergaul semakin berkembang. Faktor kelima adalah adanya bimbingan dan pengajaran dari orang lain yang biasanya menjadi "model” bagi anak. Bimbingan dan pengajaran dalam bergaul hendaknya dilakukan oleh seseorang yang dapat dijadikan model atau contoh yang baik dalam pergaulan bagi anak. Faktor keenam yaitu adanya bimbingan dan pengajaran yang secara sengaja diberikan oleh orang yang dijadikan "model" bergaul yang baik bagi anak. Walaupun kemampuan sosialisasi ini dapat pula berkembang melalui pengalaman bergaul atau dengan meniru perilaku orang lain dalam bergaul, tetapi akan lebih efektif bila ada bimbingan dan pengajaran yang secara sengaja diberikan oleh orang yang dapat dijadikan model atau contoh bergaul yang baik untuk anak.

Faktor selanjutnya yang berpengaruh terhadap kemampuan interaksi sosial anak adalah adanya kemampuan berkomunikasi yang baik yang dimiliki anak. Anak dituntuk untuk memiliki kemampuan berkomunikasi yang baik dengan orang lain agar dapat mengembangkan kemampuan sosialnya. Kemampuan berkomunikasi ini merupakan inti dari sosialisasi atau interkasi sosial. Faktor terakhir yang juga dapat mempengaruhi kemampuan interaksi soisal anak adalah adanya kemampuan berkomunikasi yang dapat membicarakan topik yang dimengerti dan menarik baagi orang lain yang menjadi lawan bicara. Ketika berkomunikasi dengan orang lain, anak tidak hanya dituntut untuk berkomunikasi dengan kata-kata yang dapat dipahami, tetapi juga dapat membicarakan topik yang dapat dimengerti dan menarik untuk orang lain yang menjadi lawan bicaranya. Kemampuan anak untuk berinteraksi sosial dipengaruhi oleh berbagai hal antara lain, interaksi dengan keluarga, perkembangan pikiran anak, munculnya rasa percaya diri anak, dan kebutuhan akan perhatian dan empati.
Kesemuanya itu akan membentuk pola interaksi sosial anak dengan orang lain.

Kesulitan belajar adalah suatu kondisi proses belajar yang ditandai hambatan-hambatan tertentu untuk mencapai hasil belajar. Kesulitan belajar juga diartikan sebagai suatu keadaan di mana siswa tidak dapat belajar sebagaimana mestinya. Kesulitan belajar di sini menunjuk pada kesulitan yang dimanifestasikan dalam bentuk kesulitan yang nyata dalam kemahiran dan penggunaan kemampuan mendengarkan, bercakap-cakap, membaca, menulis, menalar, atau kemampuan dalam bidang studi tertentu. Kesulitan belajar adalah suatu kondisi di mana siswa tidak dapat belajar secara wajar disebabkan adanya ancaman, hambatan ataupun gangguan dalam belajar.

Ada beberapa kasus kesulitan dalam belajar yaitu kasus kesulitan dengan latar belakang kurangnya motivasi dan minat belajar. Kasus kesulitan yang berlatar belakang sikap negatif terhadap guru, pelajaran, dan situasi belajar. Kasus kesulitan dengan latar belakang kebiasaan belajar yang salah. Kasus kesulitan dengan latar belakang ketidakserasian antara kondisi obyektif keragaman pribadinya dengan kondisi obyektif instrumental impuls dan lingkungannya.

Dalam menghadapi kesulitan anak ini guru dapat diibaratkan sebagai pembimbing perjalanan (journey), yang berdasarkan pengetahuan dan pengalamannya betanggung jawab atas kelancaran perjalanan itu.dalam hal ini istilah perjalanan tidak hanya menyangkut fisik tetapi juga perjalanan mental, emosional, kreatifitas, moral, dan spiritual yang lebih dalam dan kompleks. Sebagai pembimbing, guru harus merumuskan tujuan secara jelas, menetapkan waktu perjalanan, serta menilai kelancaranya sesuai dengan kebutuhan dan kemampuan peserta didik. Tanpa bimbingan guru, anak didik akan mengalami kesulitan dalam 


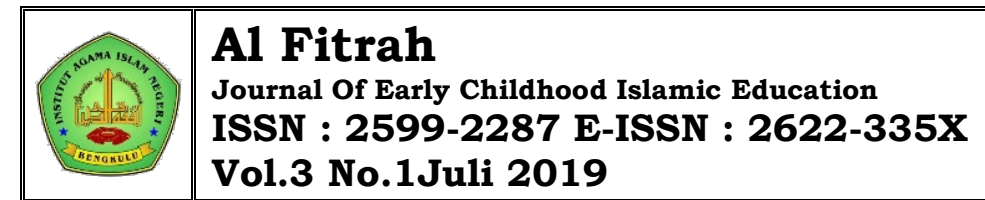

Kesulitan Anak Usia Dini dalam Berinteraksi Sosial di TK N 09

Puspita RO, Nurlaili, Vol.3 No.1Juli 2019

Ahmad Syarifin

menghadapi perkembangan dirinya.
Kekurangmampuan anak didik menyebabkan lebih banyak tergantung pada bantuan guru. Tetapi semakin dewasa ketergantungan anak didik semakin berkurang. Pembimbing dapat diartikan sebagai seseorang yang menuntun anak didik dalam perkembangannya dengan jalan memberikan lingkungan dan arah yang sesuai dengan tujuaan pendidikan

\section{Kesimpulan}

Berdasarkan pada temuan dan pembahasan hasil penelitian, maka dapat disimpulknan bahwa kegiatan bermain pada anak di TK Negeri 09 Bengkulu Selatan menekankan pada peranannya dalam kemampuan interaksi sosial anak, karena kemampuan ini berperan penting bagi pekembangan anak. Dalam mengikuti pembelajaran ada kesulitan anak dalam berinteraksi sosial diantaranya yaitu kurang peduli dan lebih suka sendirian, sesekali mau berinteraksi dengan teman-temannya namun hanya sebatas teman yang berada disebelahnya, kurang percaya diri dalam berinteraksi dengan teman-temannya dan cenderung kurang berani untuk berbicara langsung. Sedangkan untuk minat tertahan karena mereka kurang berani untuk berinteraksi dan cenderung takut. Faktor yang mempengaruhi kesulitan anak dalam berinteraksi sosial ini yaitu adalah perbedaan umur, kurangnya rasa percaya diri dan keberanian anak serta minat meskipun tidak berperan besar.

\section{Daftar Pustaka}

Chulsum dan Novia. Kamus Besar Bahasa Indonesia. Surabaya: Kashiko

Elisabeth B Hurlock. 1991. Child Development (Terjemahan). Jakarta: Gelora Aksara Pratama
Kartini Kartono.2010. Psikologi
Perkembangan. akarta: Rineka Cipta.
Lexy J Moelong.2010.Meodologi Penelitian Kualitatif.Jakarta: Rosda

Muhibbin Syah.2009. Psikologi Belajar.Jakarta: Rajawali Pers.

M. Ramli. 2005. Pendampingan Perkembangan Anak Usia Dini. Jakarta: Depdiknas, Dirjen Pendidikan Tinggi, Direktorat Pembinaan Pendidikan Tenaga Kependidikan dan Ketenagaan Perguruan Tinggi,

Nana Syaodih Sukmadinata. 2008.

Landasan Psikologis Pendidikan.

Bandung: Remaja Rosdakarya

Ramayulis.2008. Ilmu Pendidikan Islam. Jakarta: Kalam Mulia

Sarimaya Farida, Sertifikasi Guru.Bandung:

Yrama Widya

Syaiful Bahri Djamarah.2005. Guru dan Anak Didik Dalam Interaksi Edukatif. Jakarta: PT Asdi Mahasatya,

Undang-undang RI Nomor 20,.2003. Tentang Sistem Pendidikan Nasional.Bandung: Citra Umban,

Undang-Undang RI Nomor 14 tahun 2005, Tentang Guru dan Dosen

Yeni Rachmawati \& Euis Kurniati. 2005. Strategi Pengembangan Kreativitas Pada Anak UsiaTaman Kanak Kanak. (Jakarta: Departemen Pendidikan Nasional,Direktorat Jendral Pendidikan Tinggi,Direktorat Pembinaan Pendidikan Tenaga Kependidikan dan Ketenagaan Perguruan Tinggi 